Revta brasil. Bot., São Paulo, V.23, n.2, p.133-141, jun. 2000

\title{
Growth and leaf demography of two Cecropia species
}

\author{
FLAVIO A.M. SANTOS ${ }^{1}$
}

(received: September 11, 1998; accepted: December 30, 1999)

\begin{abstract}
Growth and leaf demography of two Cecropia species). Allometry, growth and leaf demography of two Cecropia species, one with ant mutualist (C. glazioui) and another without it (C. hololeuca), were studied in an Atlantic Rain Forest area in the State of Rio de Janeiro, SE Brazil. Stem diameter was allometrically related to height in both species. Cecropia glazioui showed higher annual growth rates and longer internodes than $C$. hololeuca. Leaf phenology showed a seasonal pattern in both species, but the number of leaves on each plant was more variable along the year in $C$. hololeuca than in $C$. glazioui. Survivorship curves for leaves were intermediate between Deevey's Type I and Type II curves, with young leaves of C. glazioui showing a greater survival rate and life expectancy than those of $C$. hololeuca. Low variability in leaf production throughout the year and high survival rate for young leaves of $C$. glazioui may be characteristics related to its association with ants.
\end{abstract}

RESUMO - (Crescimento e dinâmica foliar de duas espécies de Cecropia). Alometria, crescimento e demografia de folhas de uma espécie de Cecropia associada com formigas (C. glazioui) e outra não (C. hololeuca) foram estudadas em área de Floresta Pluvial Attântica, no SE Brasil. As relações entre os diâmetros dos caules e as alturas das plantas foram semelhantes nas duas espécies. Cecropia glazioui apresentou maior crescimento anual e entrenós maiores que $C$. hololeuca. A emergência e a mortalidade de folhas foram sazonais nas duas espécies, sendo o número de folhas mais variável ao longo do ano em $C$. hololeuca que em $C$. glazioui. As curvas de sobrevivência de folhas foram intermediárias entre os Tipo I e Tipo II de Deevey, sendo que folhas jovens de C. glazioui apresentam probabilidades de sobrevivência e expectativas de vida maiores que as de C. hololeuca. A produção de folhas menos variável durante o ano, e a maior sobrevivência de folhas novas em C. glazioui podem estar relacionadas à associação com formigas.

Key words - Allometry, Atlantic Rain Forest, Cecropia, growth, leaf demography

\section{Introduction}

The growth of a plant is determined in part by the dynamics and longevity of its leaves. Trees of the humid tropics show several seasonal patterns of leaf activity (Givnish 1984). Some hypotheses have been advanced to explain the adaptive significance of leaf life span. These hypotheses have usually been developed in specific environmental contexts to explain the deciduous-evergreen dichotomy (Chabot \& Hicks 1982). The pattern of leaf production by evergreen plants ranges from almost continuous production in some pioneer species, to discontinuous leaf flushes in many mature-phase species (Coley 1983). Leaf ageing and senescence are currently interpreted as part of a programmed allocation of resources within the plant, and physiological ageing and leaf life span seem to be part of a more general adaptive strategy of plants (Thomas \& Stoddart 1980, Chabot \& Hicks 1982).

Leaf dynamics has been correlated with primary productivity (Franco 1985), litterfall patterns, sea-

1. Departamento de Botânica, Instituto de Biologia, Universidade Estadual de Campinas, Caixa Postal 6109, 13083-970 Campinas, SP, Brasil. e-mail: fsantos@unicamp.br sonality, successional status and herbivore pressure (Chabot \& Hicks 1982, Coley 1983). It has been suggested that young leaves of early successional species are difficult for herbivores to find because they are unpredictable in time and space (Coley et al. 1985). Moreover, they may exhibit less costly defenses that are effective against unspecialized herbivores (qualitative defenses). On the other hand, mature leaves of late successional species are predictable and these species may invest in costly broadspan defenses (quantitative defenses) (Feeny 1976, Coley 1983, 1986, 1988). Thus, the phenological patterns of leaf production and leaf longevity may indicate the type of defense a given species should posses (Coley et al. 1985).

Cecropia species are common in the Neotropical flora. They are fast-growing trees characteristic of disturbed sites and early stages of forest succession (Davis 1970). Most species within this genus are inhabited by ants. The significance of the Cecropia-ants association has been discussed elsewhere (see Janzen 1969, 1973, Berg 1978, Luizão \& Carvalho 1981, Andrade \& Carauta 1982). There is ample evidence that ants are effective defenders of Cecropia plants (Janzen 1969, Schupp 1987).

The growth and survival of the ant colonies that inhabit Cecropia plants depend on the growth and 
leaf production rates of the plants. This mutualistic relationship suggests that plants with ant mutualists should show higher growth rates, higher leaf survival rates and leaf longevity than those without ant association. Thus, considering species of Cecropia with and without ant association, differences in allometry, growth and leaf demography between these species could be expected.

The goals of this study were to examine allometry, growth, leaf life span and rates of emergence and death of leaves in two Cecropia species occurring in the same habitat, one associated with ants and the other not associated. I addressed the following questions: Are there differences in allometry and growth between species? Are there differences in leaf dynamics and leaf life span between species? Can the differences be related to ant association?

\section{Material and methods}

The study was carried out in an area of tropical moist Atlantic Forest, $370 \mathrm{~m}$ above sea level (located around the geographical coordinates of $22^{\circ} 27^{\prime} \mathrm{S}$ and $42^{\circ} 52^{\prime} \mathrm{W}$ ), in the municipality of Piraí, State of Rio de Janeiro, Southeastern Brazil. The region has a wet season, extending from September to May, with a maximum of rainfall in January, and a dry season, extending from June to August, with a minimum of rainfall in July (Nimer 1977). This pattern was observed, with little variations, for 1983 and 1984 (figure 1), respectively the year before and the year of study.

Three species of Cecropia occur in this area: $C$. pachystachya Trécul, C. glazioui Sneth. and C. hololeuca Miq. The last two species were chosen for this study because they co-occur in the same habitat and are similar in size (Sposito 1999). Typically, the ventral petiole base of Cecropia leaves has a hairy mat (the trichilia) that produces glycogen-rich Müllerian bodies (Rickson 1971), while the leaf is being formed and for a short time after it has expanded (Folgarait \& Davidson 1994). The quantity of Müllerian bodies produced by a plant is a function of the rate of leaf production, since trichilia of old leaves are inactive (Folgarait \& Davidson 1994, Folgarait et al. 1994). Adult trees of $C$. glazioui are commonly inhabited by large colonies of Azteca ants (generally A. muelleri and, to a lesser extent, A. alfari), which occupy its hollow stems and branches, and consume the Müllerian bodies. Cecropia hololeuca has neither trichilia nor Müllerian bodies, and is not associated with specialized ants. This is the only extra-Amazonian species of the genus in Brazil that does not have an association with ants (Berg 1996).

Height (measured up to the base of apical stipule), stem diameter (measured at the base) and number of leaves were recorded for 63 unbranched individuals $(0.2$ to $4.0 \mathrm{~m}$ tall) of the two species ( 18 of $C$. glazioui and 45 of $C$. hololeuca - differences in number of individuals were due to both different abundance of individuals in the area and death of plants during the study period).

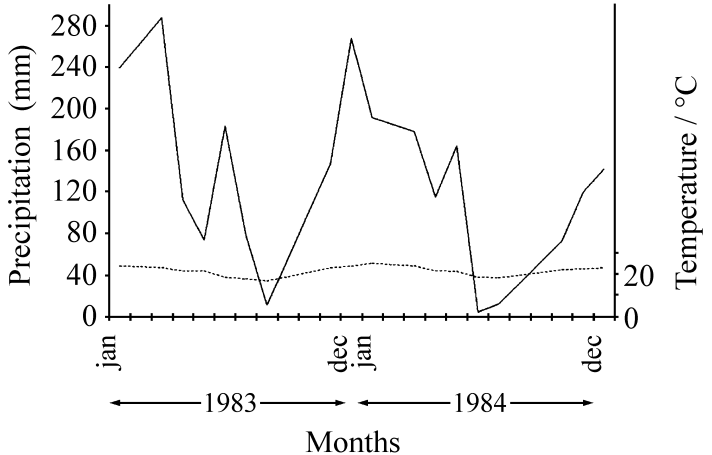

Figure 1. Monthly precipitation $(\mathrm{mm})$ and mean temperature $\left({ }^{\circ} \mathrm{C}\right)$ in Piraí, RJ, for 1983 and 1984. Data were obtained from $6^{\circ}$ Distrito de Meteorologia do Rio de Janeiro (22 $38^{\prime} \mathrm{S}$ and $43^{\circ} 54^{\prime} \mathrm{W}, 367 \mathrm{~m}$ a.s.1.). Precipitation (一), Temperature (....).

Standard regressions were used to describe allometric patterns Variables were $\log _{10}$-transformed before regressions were performed (King 1990, Kohyama \& Hotta 1990, Niklas 1994). Comparisons between regression lines were made by an ANCOVA (Snedecor \& Cochran 1980, Zar 1984).

To monitor growth, the individuals were marked and followed for seven recording periods in 1984 (February, March, May, June, August, September and October). Mean growth rates were estimated for each individual through the number and sizes of new internodes produced in each recording period, using the following formulae: GRI $=\mathrm{NI} \cdot \Delta \mathrm{t}^{-1} ; \mathrm{GRH}=(\Sigma \mathrm{SI}) \cdot \Delta \mathrm{t}^{-1}$; MSI $=(\Sigma S I) \cdot \mathrm{NI}^{-1} \cdot \Delta \mathrm{t}^{-1}$; where: GRI $=$ growth in number of internodes, $\mathrm{GRH}=$ growth in height, MSI = mean size of internodes, $\mathrm{NI}=$ number of internodes produced during a sample period, $\mathrm{SI}=$ size of internodes produced during a sample period, $\Delta \mathrm{t}=$ days between samples.

All leaves on each plant were marked and the rates of emergence and death were obtained for each of the seven sampled periods. Emergence was considered to begin when the stipule tore and the leaf was exposed. A leaf was considered dead when no green tissue remained on it, or when it detached from the stem. Leaves that had been damaged by handling were excluded from further analysis.

The rates of emergence (bl) and death (dl) were estimated by dividing the number of new or dead leaves by the number of days between two sample periods. Recruitment rates (rl) were estimated by the difference between emergence and death rates. Leaf turnover rate was estimated by dividing the emergence rate by the death rate (Costa et al. 1991). Mean leaf turnover rate values were compared by a t-test between species (Zar 1984).

Growth rates and rates of leaf emergence and death were compared by observations of overlap in confidence intervals of median in box-plots (McGill et al. 1978). Variations in size of internodes of each individual was represented by a $\log _{10}$ transformation of the variance of internode size measured in each individual. A log-transformation was used to obtain homoscedascity (Zar 1984).

The ages of leaves already present on plants at the first observation were estimated with the aid of the mean emergence rate calculated for each individual and by taking into account the 
position of the leaves on the plant. The age of leaves produced during the study period was estimated by using the emergence rate. The age to death was considered as the age at which a leaf was last seen on a plant. The parameters of leaf life tables were calculated for age intervals of 30 days. Survivorship curves for leaves of the two species were compared by a Peto and Peto log-rank test (Pyke \& Thompson 1986). Half-life (in days) was estimated by the formulae (Watkinson 1986): $t_{0.5}=(t \cdot \ln 2) .\left(\ln \mathrm{N}_{0}\right.$ $\left.-\ln \mathrm{N}_{\mathrm{t}}\right)^{-1}$, where: $\mathrm{t}=$ maximum longevity in days, $\mathrm{N}=$ number of leaves, and compared by a t-test for differences between species (Zar 1984).

\section{Results}

Stem diameter was allometrically related to height in both Cecropia species (figure 2) and there were no differences in allometric relations between species (between slopes: $\mathrm{F}_{1: 34}=0.859, \mathrm{p}=0.364$; between intercepts: $F_{1: 35}=2.777, p=0.101$ ).

Individual growth rates in height varied between 0.12 and $1.44 \mathrm{~m}^{-\mathrm{yr}^{-1}}$ in C. glazioui and between 0.04 and $2.76 \mathrm{~m} \mathrm{yr}^{-1}$ in C. hololeuca. In spite of the higher growth of some individuals of $C$. hololeuca, the growth rate of the two species was similar (figure 3a). Growth in Cecropia species can be affected by the number and size of internodes produced. The species studied did not differ in number of internodes produced per year (figure $3 b$ ) and in mean size of internode produced by individual (figure $3 \mathrm{c}$ ), but the internode size was more variable in individuals of $C$. glazioui than in C. hololeuca (figure 3d).

Both species showed similar variation throughout the year in growth rates, in number of internodes produced and in internode length (figure 4), with low values in June and August. However, the internode length seems to be more variable throughout the year in C. hololeuca than in C. glazioui (figure 4e-f).

Individual rates of leaf emergence (bl), death (dl) and net change in the number of leaves (rl) did not differ between species (figure 5). Emergence rates (bl) were similarly variable along the year for the two species, and so were the death rates (dl) (figure 5a-d). C. hololeuca showed higher variation in rl than C. glazioui (figure 5e-f). C. hololeuca showed periods (May and November) with higher net increase (higher median values) and periods (June) with higher net decrease (lower median value) in the number of leaves. The absence of a relation between emergence (B) and death (D) rates in $C$.

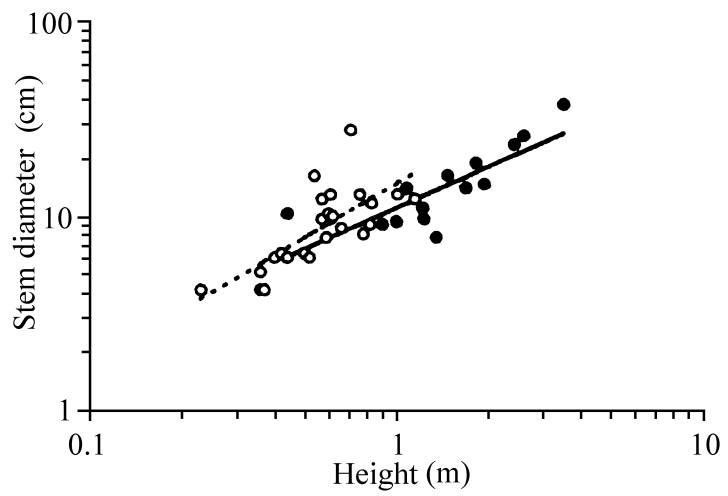

Figure 2. Allometry of stem diameter (D) and height $(\mathrm{H}): \log \mathrm{D}=$ $1.035+0.698 \log \mathrm{H} ; \mathrm{r}^{2}=0.633, \mathrm{p}=0.001$ (Cecropia glazioui) and $\log \mathrm{D}=1.161+0.925 \log \mathrm{H} ; \mathrm{r}^{2}=0.530, \mathrm{p}<0.001$ (Cecropia hololeuca). Cecropia glazioui (•), Cecropia hololeuca (o).

hololeuca $\left(\mathrm{D}=16.287+0.278 \mathrm{~B}, \mathrm{r}^{2}=0.050, \mathrm{p}=\right.$ 0.158 ) seems to account for the greater variation in number of leaves in this species, in contrast with $C$. glazioui where emergence and death rates were related $\left(\mathrm{D}=12.961+0.437 \mathrm{~B}, \mathrm{r}^{2}=0.206, \mathrm{p}=0.049\right)$ and the number of leaves was less variable. Mean leaf turnover rate $(\mathrm{bl} / \mathrm{dl})$ differed between species $(\mathrm{t}=2.598, \mathrm{p}=0.048)$, being higher for $C$. glazioui $(1.47 \pm 0.25)$ than for $C$. hololeuca $(1.01 \pm 0.57)$.

Leaf emergence rates were density independent (considering the population of leaves in one individual) for both species $\left(\mathrm{r}^{2}=0.126, \mathrm{p}=0.133\right.$ for $C$. glazioui and $\mathrm{r}^{2}=0.083, \mathrm{p}=0.064$ for $C$. hololeuca), while leaf death rates in $C$. hololeuca was densitydependent (plants with more leaves showed higher death rates; Death rate $=5.348+2.292$ number of leaves, $\mathrm{r}^{2}=0.197, \mathrm{p}=0.003$ ), but not in $C$. glazioui (Death rate $=17.890+0.782$ number of leaves, $r^{2}=0.050, p=0.359$ ).

Leaf life tables (table 1) and survivorship curves (figure 6) showed a similar pattern for both species. Survivorship curves were intermediate between Deevey's Type I and Type II curves and did not differ significantly between species (LR $=2.574$, $\mathrm{p}>0.05$ ). However, leaves of $C$. glazioui had a greater life expectancy and lower mortality rates than those of C. hololeuca, up to 120 days (table 1). Leaves of $C$. glazioui had a half-life 34 percent greater and mean longevity 18 percent greater than those of $C$. hololeuca (table 2). 

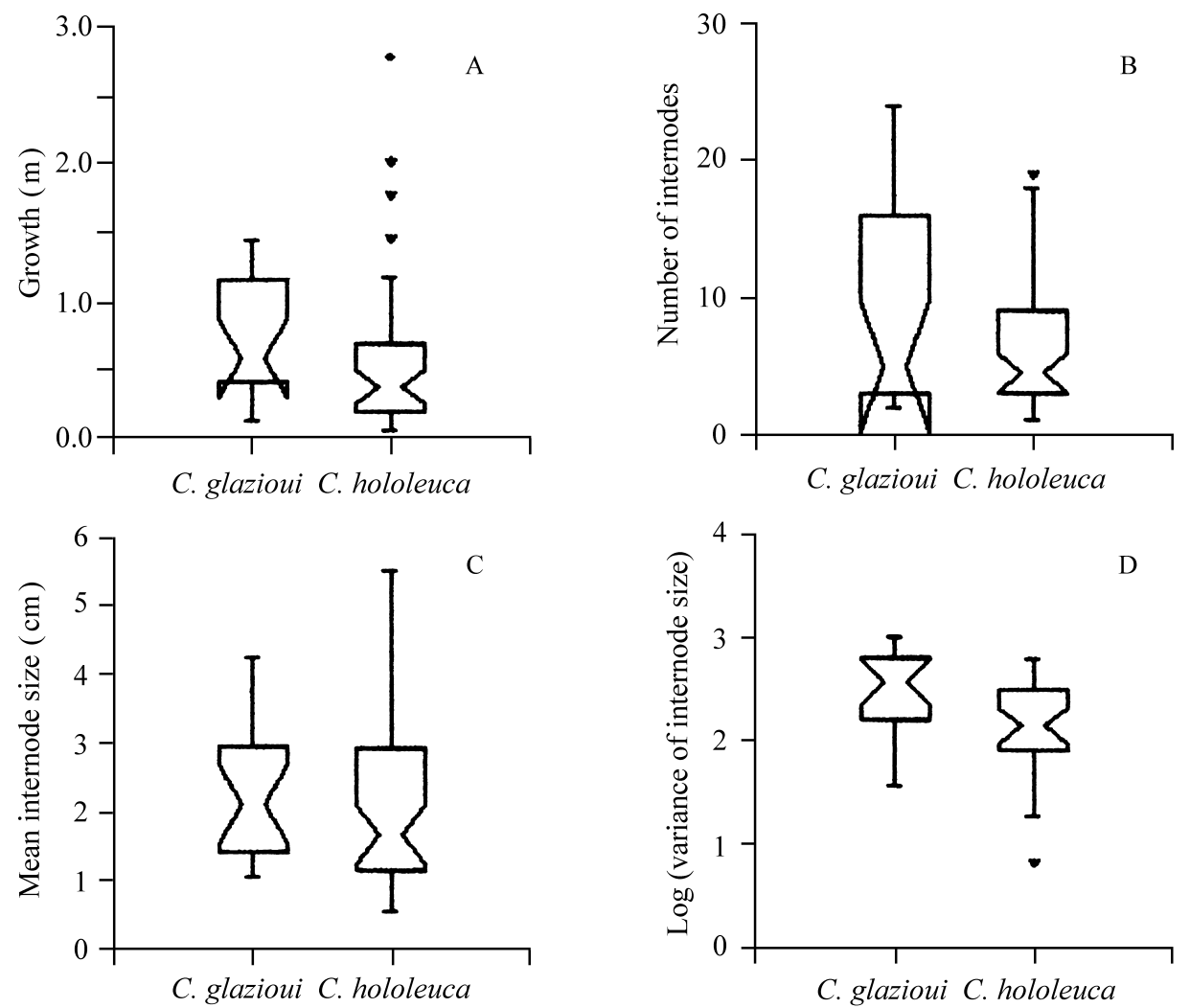

Figure 3. Box-plot of growth characteristics for individuals of Cecropia glazioui and C. hololeuca in Piraí, RJ. A. growth rates (m.yr $\left.{ }^{-1}\right)$; B. number of internodes produced per year; C. mean internode size $(\mathrm{cm})$; D. $\log _{10}$ variance of internode size. In a box-plot graph, the box comprises $50 \%$ of data. Boxes are notched (narrowed) at the median and return to full width at the lower and upper $95 \%$ confidence interval values. Inner and outer fences are defined by interquartile ranges. Asterisks are "outside values" and "far outside values" are circles. If the confidence intervals do not overlap, the median of the species are different (McGill et al. 1978).

\section{Discussion}

Similar allometric relations are expected in plants within the same life form and similar ecological traits (King 1990, Kohyama \& Hotta 1990). The relations observed here are comparable to those obtained by Alvarez-Buylla \& Martínez-Ramos (1992) for unbranched individuals of Cecropia obtusifolia. This suggests that the allometric relations between stem diameter and height in Cecropia species are a phylogenetic characteristic and are not affected by ant association, in spite of differences in internodes length.

The estimates of individual growth rates obtained here are in the range obtained by Schupp (1987) for Cecropia obtusifolia (between 0.05 and $\left.2.00 \mathrm{~m} . \mathrm{yr}^{-1}\right)$, but are low compared with the growth rates obtained for $C$. peltata $\left(1.0\right.$ to $\left.10.6 \mathrm{~m} . \mathrm{yr}^{-1}\right)$ and $C$. obtusifolia (0.7 to $\left.12.4 \mathrm{~m} . \mathrm{yr}^{-1}\right)$ in Costa Rica (Davis 1970), for C. insignis (4.9 m.yr ${ }^{-1}$ ) in Barro Colorado (Brokaw 1987) and for C. obtusa (0.14 to 6.52 m.yr ${ }^{-1}$ ) in Carajás, PA, Northern Brazil (F.A.M. Santos \& J.D. Hay, unpublished data).

Differences in internode length within individuals were observed for $C$. peltata and C. obtusifolia in Costa Rica and correlated with dry and wet seasons (Davis 1970). The same seasonal patterns were observed for C. obtusa in Northern Brazil (F.A.M. Santos \& J.D. Hay, unpublished data). These differences attributed to rainfall seasonality may be used to infer age and past growth in these plants (Davis 1970) and to estimate age of gaps. Seasonality of precipitation seems to have a greater effect on the size of internodes of $C$. hololeuca than of $C$. glazioui, 

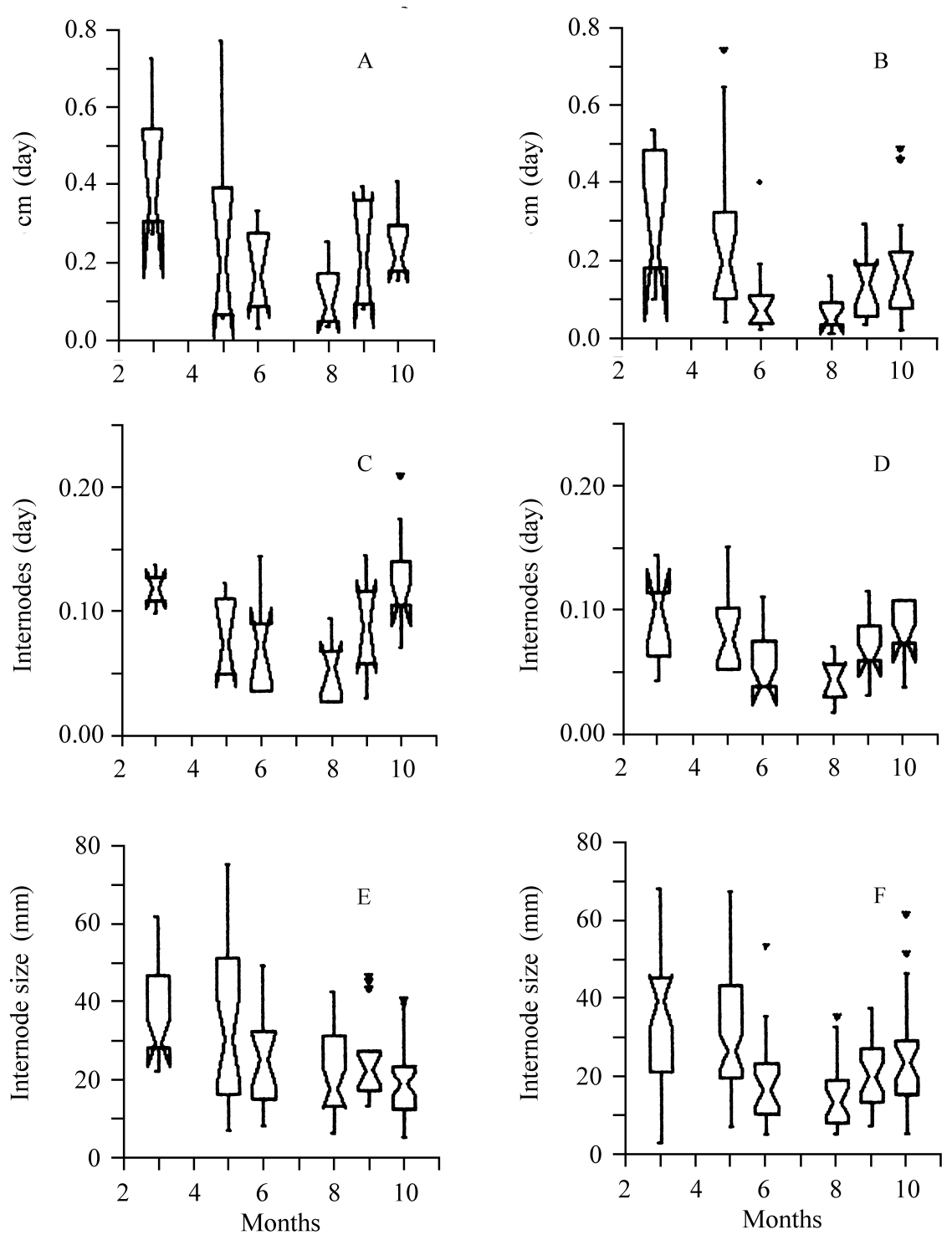

Figure 4. Box-plot of growth characteristics for individuals of Cecropia glazioui (A, C, E) and Cecropia hololeuca (B, D, F) in Piraí,

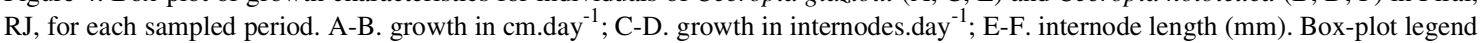
as in figure 3.

with a smaller variation in internode length in $C$. glazioui than in C. hololeuca. However, internode sizes seem to be more variable among individuals of C. glazioui than of $C$. hololeuca.

Leaf phenology showed a seasonal pattern in both species, the number of leaves being more variable in $C$. hololeuca during the year than in $C$. glazioui. Milton (1991) found that leaf production in Cecropia insignis for two years varied between 51.8 \pm 6.0 and $51.0 \pm 7.0$ leaves. $\mathrm{yr}^{-1}$, with a peak of production of new leaves in the late rainy season. The two species studied here showed a similar pattern in time, in spite of having lower values for leaf production rate. A greater leaf turnover rate in C. glazioui may account for a minor seasonal variability in the number of leaves. In turn, this maintains the availability of the food resources for ants more constant, 
Table 1. Life tables for leaves of Cecropia glazioui and $C$. hololeuca. $\mathrm{x}$ : age classes (in days); $\mathrm{N}_{\mathrm{x}}$ : number of leaves in the age class $\mathrm{x} ; \mathrm{l}_{\mathrm{x}}=\mathrm{Nx} / \mathrm{N}_{0} ; \mathrm{d}_{\mathrm{x}}=\mathrm{l}_{\mathrm{x}}-\mathrm{l}_{\mathrm{x}+1} ; \mathrm{q}_{\mathrm{x}}=\mathrm{d}_{\mathrm{x}} / \mathrm{l}_{\mathrm{x}} ; \mathrm{e}_{\mathrm{x}}$ (in days) $=\mathrm{T}_{\mathrm{x}}$ $30 / \mathrm{N}_{\mathrm{X}}\left(\right.$ where $\mathrm{T}_{\mathrm{X}}=\Sigma \mathrm{L}_{\mathrm{x}}$ and $\left.\mathrm{L}_{\mathrm{x}}=\left(\mathrm{N}_{\mathrm{X}+1}+\mathrm{N}_{\mathrm{x}}\right) / 2\right)$.

\begin{tabular}{lccccc}
\hline $\mathrm{x}$ & $\mathrm{N}_{\mathrm{x}}$ & $\mathrm{l}_{\mathrm{x}}$ & $\mathrm{d}_{\mathrm{x}}$ & $\mathrm{q}_{\mathrm{x}}$ & $\mathrm{e}_{\mathrm{x}}$ \\
\hline \multicolumn{5}{c}{ Cecropia } & glazioui \\
0 & 147 & 1.000 & 0.177 & 0.177 & 112.55 \\
30 & 121 & 0.823 & 0.163 & 0.198 & 103.51 \\
60 & 97 & 0.660 & 0.136 & 0.206 & 95.41 \\
90 & 77 & 0.524 & 0.116 & 0.221 & 86.30 \\
120 & 60 & 0.408 & 0.082 & 0.200 & 76.50 \\
150 & 48 & 0.326 & 0.122 & 0.375 & 61.88 \\
180 & 30 & 0.204 & 0.061 & 0.300 & 60.00 \\
210 & 21 & 0.143 & 0.048 & 0.333 & 49.29 \\
240 & 14 & 0.095 & 0.054 & 0.571 & 36.43 \\
270 & 6 & 0.041 & 0.014 & 0.333 & 35.00 \\
300 & 4 & 0.027 & 0.027 & 1.000 & 15.00 \\
Cecropia & hololeuca & & & & \\
0 & 323 & 1.000 & 0.204 & 0.204 & 96.18 \\
30 & 257 & 0.796 & 0.186 & 0.234 & 87.02 \\
60 & 197 & 0.610 & 0.161 & 0.264 & 78.96 \\
90 & 145 & 0.449 & 0.136 & 0.303 & 71.90 \\
120 & 101 & 0.313 & 0.130 & 0.416 & 66.68 \\
150 & 59 & 0.183 & 0.059 & 0.322 & 73.47 \\
180 & 40 & 0.124 & 0.037 & 0.300 & 71.25 \\
210 & 28 & 0.087 & 0.025 & 0.286 & 65.36 \\
240 & 20 & 0.062 & 0.022 & 0.350 & 55.50 \\
270 & 13 & 0.040 & 0.012 & 0.308 & 47.31 \\
300 & 9 & 0.028 & 0.016 & 0.556 & 31.67 \\
330 & 4 & 0.012 & 0.009 & 0.750 & 22.50 \\
360 & 1 & 0.003 & 0.003 & 1.000 & 15.00 \\
\hline & & & & &
\end{tabular}

Table 2. Half-life (in days) and mean (arithmetic means \pm standard deviations) longevity (in days) of leaves of Cecropia glazioui and C. hololeuca.

\begin{tabular}{lcc}
\hline & C. glazioui & C. hololeuca \\
\hline Half-life & 57.70 & 43.19 \\
Mean longevity* & $112.79 \pm 82.13$ & $95.33 \pm 76.95$ \\
\hline
\end{tabular}

*Comparison between species: $\mathrm{t}=2.179, \mathrm{p}=0.030$.
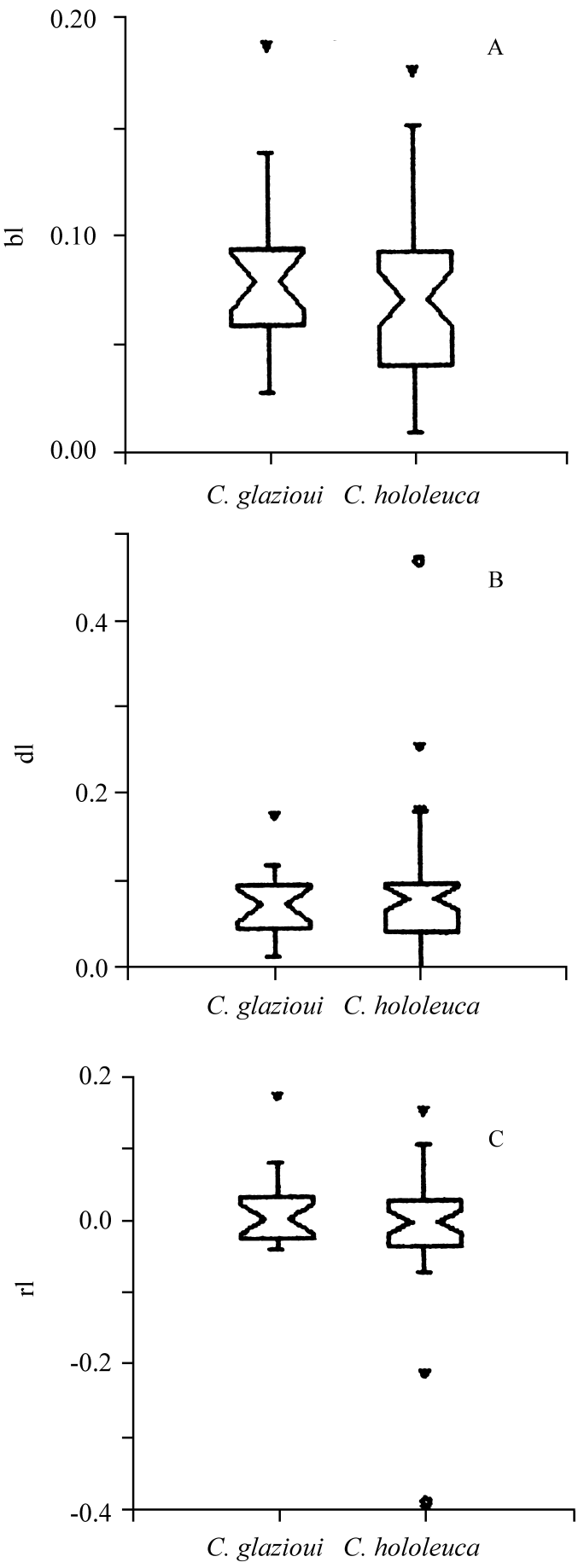

Figure 5. Box-plots of leaf dynamics characteristics for individuals of Cecropia glazioui and C. hololeuca in Piraí, RJ. A. rates of leaf emergence (bl); B. rates of leaf death (dl); C. net change in the number of leaves (rl). Box-plot legends as in figure 3. 

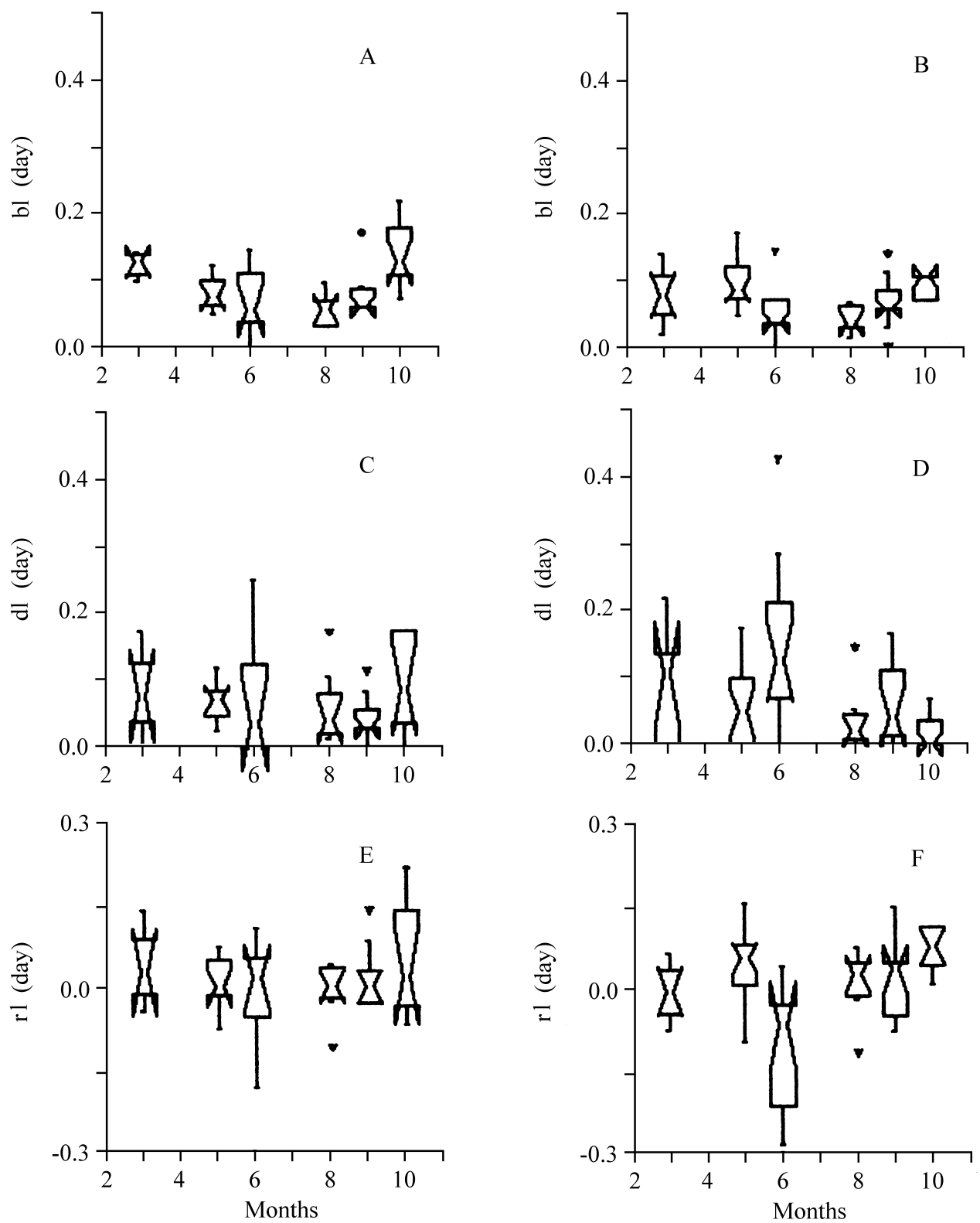

Figure 6. Box-plot of leaf dynamics characteristics for individuals of Cecropia glazioui (A, C, E) and C. hololeuca (B, D, F) in Piraí, $\mathrm{RJ}$, for each sampled period. A-B. leaf emergence rate $\left(\right.$ bl.day $\left.^{-1}\right)$; C-D. death rate $\left(\right.$ dl.day $\left.^{-1}\right)$; E-F. leaf recruitment rate $\left(\right.$ rl.day $\left.{ }^{-1}\right)$. Box-plot legend as in figure 3 .

since Müllerian bodies are produced only by new leaves.

Gap species grow in microhabitats with high availability of resources, and they can maintain fast growth and high leaf turnover rates and, because of this, leaves generally have short life spans of about
$6.9 \pm 3.9$ months (Coley \& Aide 1991). The figures obtained for the two Cecropia species fall in this range, but they are high if compared with leaf longevity obtained by Núñez-Farfán \& Dirzo (1989) for C. obtusifolia (means $=67.89$ to 74.82 days, with maximum longevity about 120 days). 


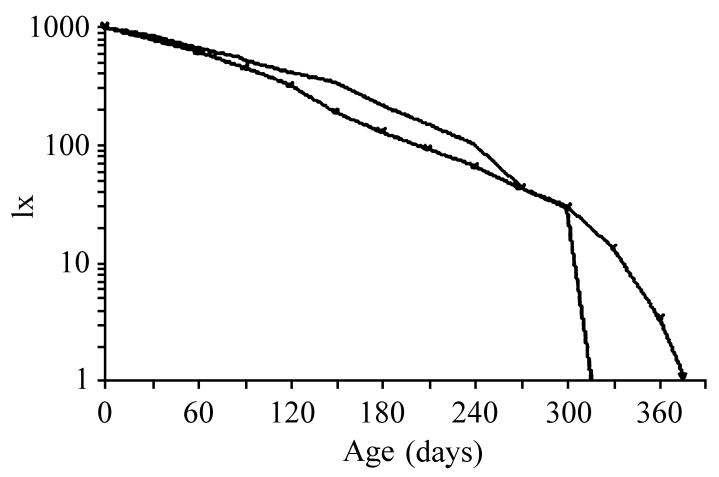

Figure 7. Survival curves for leaves of Cecropia glazioui (- - - $)$ and $C$. hololeuca $(-\mathrm{x}-)$.

Leaves of $C$. glazioui showed higher survival and greater life expectancy than those of $C$. hololeuca. The higher chances of survival and greater life expectancy of $C$. glazioui leaves may be related to: (a) protection against herbivory conferred by their associated Azteca ants; (b) an increase in nutrient supply from ant rejects; (c) an increase in photosynthetic life of leaves due to cleaning of epiphylls and pathogens from leaf surface by the ants; or (d) differences in cost-benefits in the production and maintenance of leaves between the two species.

As time of damage is important in determining the impact of herbivory, the differences in survival of young leaves (up to 120 days) suggests that the ants are important for the defense of young $C$. glazioui leaves. On the other hand, this advantage in older leaves ceases and the survival rates are greater for $C$. hololeuca. This age (about 120 days) must be the time that the leaf trichilia activity stopped in $C$. glazioui. Consequently, the ant activity in these leaves is smaller and the importance of the ant defense is reduced. The greater maximum leaf life expectancy of $C$. hololeuca is in agreement with a slower turnover of its leaves and suggests that the costs for maintaining ants through the production of Müllerian bodies surpass the costs of chemical defenses against herbivores. An evaluation of ant colonization, production rate of Müllerian bodies, chemical compounds, and the herbivory rate in young and old leaves of these two species could elucidate some of these aspects.
Acknowledgements - This research was supported by the Brazilian National Council for the Development of Research and Technology (CNPq proc. 301746/83-4). I thank to the Departament of Ecology, Biology Institute, UFRJ, where this research was developed, F.R. Martins, H.C. Morais, C.A. Joly, W.W. Benson, G.J. Shepherd and J.D. Hay for helpful criticism and suggestions. I thank the Brazilian Special Secretary for Environment (SEMA) for permission to work at the field site and logistical assistance.

\section{References}

ALVAREZ-BUYLLA, E.R. \& MARTINEZ-RAMOS, M. 1992. Demography and allometry of Cecropia obtusifolia, a neotropical pioneer tree - an evaluation of the climax - pioneer paradigm for tropical rain forests. Journal of Ecology 80:275-290.

ANDRADE, J.C. \& CARAUTA, J.P.P. 1982. The CecropiaAzteca association: a case of mutualism? Biotropica 14:15.

BERG, C.C. 1978. Espécies de Cecropia da amazônia brasileira. Acta Amazonica 8:149-182.

BERG, C.C. 1996. Cecropia (Cecropiaceae) no Brasil, ao sul da Bacia Amazônica. Albertoa 4:213-221.

BROKAW, N.V.L. 1987. Gap-phase regeneration of three pioneer tree species in a tropical forest. Journal of Ecology 75:9-19.

CHABOT, B.F. \& HICKS, D.J. 1982. The ecology of leaf life spans. Annual Review of Ecology and Systematics 13:229259.

COLEY, P.D. 1983. Herbivory and defensive characteristics of tree species in a lowland tropical forest. Ecological Monographs 53:209-233.

COLEY, P.D. 1986. Costs and benefits of defense by tannins in a neotropical tree. Oecologia 70:238-241.

COLEY, P.D. 1988. Effects of plant growth rate and leaf lifetime on the amount and type of anti-herbivore defense. Oecologia 74:531-536.

COLEY, P.D. \& AIDE, T.M. 1991. A comparison of herbivory and plant defenses in temperate and tropical broad-leaved forests. In Plant-animal interactions: evolutionary ecology in tropical and temperate regions (P.W. Price, T.M. Lewinsohn, G.W. Fernandes \& W.W. Benson, eds.). John Wiley, New York, p.25-49.

COLEY, P.D., BRYANT, J.P. \& CHAPIN III, F.S. 1985. Resource availability and plant anti-herbivore defense. Science 230:895-899.

COSTA, C.S.B., SEELIGER, U. \& CORDAZZO, C.V. 1991. Leaf demography and decline of Panicum racemosum populations in coastal foredunes of southern Brazil. Canadian Journal of Botany 69:1593-1599.

DAVIS, R.B. 1970. Seasonal differences in internodal lengths in Cecropia trees; a suggested method for measurement of past growth in height. Turrialba 20:100-104.

FEENY, P. 1976. Plant apparency and chemical defense. In Biochemical interactions between plants and insects (J.W. Wallace \& R.L. Mansell, eds.). Plenum Press, New York, p.1-40.

FOLGARAIT, P.J. \& DAVIDSON, D.W. 1994. Antiherbivore defenses of myrmecophytic Cecropia under different light regimes. Oikos 71:305-320. 
FOLGARAIT, P.J., JOHNSON, H.L. \& DAVIDSON, D.W . 1994. Response of Cecropia to experimental removal of Müllerian bodies. Functional Ecology 8:22-28.

FRANCO, M. 1985. A modular approach to tree production. In Studies on plant demography (J. White, ed.). Academic Press, London, p.257-272.

GIVNISH, T.J. 1984. Leaf and canopy adaptations in tropical forests. In Physiological ecology of plants of the wet tropics (E. Medina, H.A. Mooney \& C. Vázquez-Yanes, eds.). Dr. W. Junk Publishers, New York, p.51-84.

JANZEN, D.H. 1969. Allelopathy by myrmecophytes: the ant Azteca as an allelopathic agent of Cecropia. Ecology 50:147-153.

JANZEN, D.H. 1973. Community structure of secondary compounds in plants. Pure \& Applied Chemistry 34:529-538.

KING, D.A. 1990. Allometry of saplings and understorey trees of a Panamanian forest. Functional Ecology 4:27-32.

KOHYAMA, T. \& HOTTA, M. 1990. Significance of allometry in tropical saplings. Functional Ecology 4:515-521.

LUIZÃO, F.J. \& CARVALHO, R.M.F. 1981. Estimativa da biomassa de raízes de duas espécies de Cecropia e sua relação com a associação ou não das plantas a formigas. Acta Amazonica 11:93-96.

McGILL, R., TUKEY, J.W. \& LARSEN, W.A. 1978. Variations of box-plots. American Statistician 32:12-16.

MILTON, K. 1991. Leaf change and fruit production in six neotropical Moraceae species. Journal of Ecology 79:1-26.
NIKLAS, K.J. 1994. Plant allometry: the scaling of form and process. University of Chicago Press, Chicago.

NIMER, E. 1977. Clima. In Geografia do Brasil: Região Sudeste (M.V. Galvão, coord.). Fundação Instituto Brasileiro de Geografia e Estatística, Rio de Janeiro, p.51-89.

NÚÑEZ-FARFAN, J. \& DIRZO, R. 1989. Leaf survival in relation to herbivory in two tropical pioneer species. Oikos 55:71-74.

PYKE, D.A. \& THOMPSON, J.N. 1986. Statistical analysis of survival and removal rate experiments. Ecology 67:240-245.

RICKSON, F.R. 1971. Glycogen plastids in Müllerian body cells of Cecropia peltata, a higher green plant. Science 173:344-347.

SCHUPP, E.W. 1987. Azteca protection of Cecropia: ant occupation benefits juvenile trees. Oecologia 70:379-385.

SNEDECOR, G.W. \& COCHRAN, W.G. 1980. Statistical methods. Iowa University Press, Ames.

SPOSITO, T.C.S. 1999. Tamanho, forma, alometria e crescimento em algumas espécies de Cecropia (Cecropiaceae) do Brasil. Tese de doutorado, Universidade Estadual de Campinas, Campinas.

THOMAS, H. \& STODDART, J.L. 1980. Leaf senescence. Annual Review of Plant Physiology 31:83-111.

WATKINSON, A.R. 1986. Plant population dynamics. In Plant Ecology (M.J. Crawley, ed.). Blackwell Scientific Publications, Oxford, p.137-184.

ZAR, J. 1984. Biostatistical analysis. Prentice Hall, New Jersey. 